\title{
The Council of Psychological Advisers
}

\section{Citation}

Cass R. Sunstein, The Council of Psychological Advisers, 67 Ann. Rev. Psychol. 713 (2016).

\section{Permanent link}

http://nrs.harvard.edu/urn-3:HUL.InstRepos:13031653

\section{Terms of Use}

This article was downloaded from Harvard University's DASH repository, and is made available under the terms and conditions applicable to Open Access Policy Articles, as set forth at http:// nrs.harvard.edu/urn-3:HUL.InstRepos:dash.current.terms-of-use\#OAP

\section{Share Your Story}

The Harvard community has made this article openly available.

Please share how this access benefits you. Submit a story.

Accessibility 
Preliminary draft 9/15/14

All rights reserved

Subject to significant revision and further editorial review

Forthcoming, Annual Review of Psychology

\title{
The Council of Psychological Advisers
}

\author{
Cass R. Sunstein*
}

\begin{abstract}
Findings in behavioral science, including psychology, have been influencing policies and reforms in many nations. "Choice architecture" can affect outcomes even if material incentives are not involved. In some contexts, default rules, simplification, and uses of social norms have been found to have even larger effects than significant economic incentives. Psychological research is helping to inform initiatives in areas that include savings, finance, highway safety, consumer protection, energy, climate change, obesity, education, poverty, development, crime, corruption, health, and the environment. No nation has created a Council of Psychological Advisers, but the role of behavioral research is likely to grow in coming years, especially in light of the mounting interest in promoting ease and simplification ("navigability"); in increasing effectiveness, economic growth, and competitiveness; and in low-cost, choice-preserving approaches. (The Appendix is a one-page list of thirtyone such approaches.)
\end{abstract}

\section{INTRODUCTION}

Many nations have some kind of Council of Economic Advisers. Should they also have a Council of Psychological Advisers (Schwartz 2012, Thaler 2012)? Perhaps they already do. Consider four initiatives from the United States:

\footnotetext{
* Robert Walmsley University Professor, Harvard Law School. This essay is scheduled for appearance in the Annual Review of Psychology, but has not been subject to final review or acceptance. I am grateful to Nicholas Epley for valuable comments and to Richard Thaler for many years of discussion. Parts of the essay draw on Cass R. Sunstein, Empirically Informed Regulation, 78 U. Chi. L. Rev. 1349 (2011).
} 
1. In 2010, the Federal Reserve Board adopted a regulation to protect consumers from high bank overdraft fees (12 C.F.R. $\S$ 205.17; Fed. Reserve System 2009). The regulation forbids banks from automatically enrolling people in "overdraft protection" programs; instead, customers have to sign up (Willis 2013). In explaining its action, the Board observed that studies have shown that "consumers are likely to adhere to the established default rule, that is, the outcome that would apply if the consumer takes no action" (Fed. Reserve System 2009). The Board also referred to the phenomenon of unrealistic optimism, suggesting that consumers might well underestimate the likelihood that they would not overdraw their accounts (Fed. Reserve System 2009).

2. In 2014, the Food and Drug Administration (FDA) proposed to revise its "nutrition facts" panel, which can be found on almost all food packages. Aware that it was obliged to identify the market failure that the regulation would address, the FDA stated that the new label could "assist consumers by making the long-term health consequences of consumer food choices more salient and by providing contextual cues of food consumption" (US FDA 2014a). The FDA noted that the "behavioral economics literature suggests that distortions internal to consumers (or internalities) due to timeinconsistent preferences, myopia or present-biased preferences, visceral factors (e.g., hunger), or lack of selfcontrol, can also create the potential for policy intervention to improve consumer welfare" (US FDA 2014a).

3. In 2010, the Environmental Protection Agency (EPA) and the Department of Transportation (DOT) adopted aggressive fuel economy standards for motor vehicles. Most of the benefits of such standards come from economic savings for consumers, which raises a puzzle: Why can't consumers choose fuel efficient cars if they want? In answering that question, the government invoked behavioral research suggesting that "consumers appear not to purchase products that are in their economic self-interest" (US EPA \& US DOT 2010). It offered a catalogue of psychological findings:

-- Consumers might be myopic and hence undervalue the long-term. 
-- Consumers might lack information or a full appreciation of information even when it is presented.

-- Consumers might be especially averse to the short-term losses associated with the higher prices of energy-efficient products relative to the uncertain future fuel savings, even if the expected present value of those fuel savings exceeds the cost (the behavioral phenomenon of "loss aversion").

-- Even if consumers have relevant knowledge, the benefits of energy-efficient vehicles might not be sufficiently salient to them at the time of purchase, and the lack of salience might lead consumers to neglect an attribute that it would be in their economic interest to consider.

4. In 2014, the FDA proposed to assert authority over a range of tobacco products. In explaining its action, it emphasized that there are "opportunities for regulation of tobacco products to enhance social welfare for the population at large. Time inconsistency exists when consumers use lower rates of discount for consequences far in the future than for consequences close to the present. Time-inconsistent consumers make current decisions that they would not make from the perspective of their future selves" (US FDA 2014b). The FDA added, "Consumers may suffer from time-inconsistent behavior, problems with self-control, addiction, and poor information, which prevent them from fully internalizing the benefits of reducing tobacco use" (US FDA 2014b).

From these examples, it should be plain that in the United States, psychological research has played a significant role in important policy domains. The relevant initiatives enlist tools such as default rules, simplification, disclosure, and social norms, and they can be found in areas that include fuel economy, energy efficiency, environmental protection, health care, and obesity. The Consumer Financial Protection Bureau, created in 2010, is particularly interested in using psychological research to protect consumers in financial markets. (Consider its mantra: "know before you owe.") Psychological findings, and behavioral science more generally, have become an important reference point for policymaking in the United States.

In 2010, the United Kingdom created a Behavioural Insights Team with the specific goal of incorporating an understanding of human 
psychology into policy initiatives. The official website states that its "work draws on insights from the growing body of academic research in the fields of behavioural economics and psychology which show how often subtle changes to the way in which decisions are framed can have big impacts on how people respond to them" (Cabinet Office 2013). The Team uses these insights to promote initiatives in numerous areas, including smoking cessation, energy efficiency, organ donation, consumer protection, tax compliance, and compliance strategies in general. The Team has enlisted the acronym "EAST" to capture its approach: Easy, Attractive, Social, and Timely (http://www.behaviouralinsights.co.uk/sites/default/files/BIT\%20Pu blication\%20EAST_FA_WEB.pdf).

The results of the Team's work include many substantial successes (for a catalogue, see http://www.behaviouralinsights.co.uk/publications). For example, (1) a psychologically informed approach increased tax payment rates from delinquent taxpayers by over 5 percentage points; (2) a message designed to prompt people to join the Organ Donor Registry added 100,000 people to the Registry in a single year; and (3) automatically enrolling individuals in pension schemes has increased saving rates for those employed by large firms in the UK from 61 percent to 83 percent. In 2014, the Team moved from the Cabinet Office to become a partly privatized joint venture, a self-described "social purpose company" owned by the government, the team's employees, and Nesta (an innovation charity). Other nations have expressed keen interest in the work of the Team, and its operations have significantly expanded. The idea of "nudge units," or behavioral insights teams, is receiving worldwide attention.

In Germany, Australia, Denmark, Sweden, Canada, Singapore, Israel, the Netherlands, South Korea, and Mexico, among others, psychological insights have been enlisted in discussions of environmental protection, financial reform, energy policy, and consumer protection. In 2014, the United States created a behavioral insights team of its own, called the Social and Behavioral Sciences Team. It is housed in the General Services Administration and run by the White House Office of Science and Technology Policy; it is engaged in a range of projects designed to test the effects of various policies, with close reference to psychological research.

Behavioral science has drawn considerable (and growing) attention in Europe more broadly. For example, a report from the European Commission, called Green Behavior, enlists behavioral science to outline policy initiatives to protect the environment 
(European Commission 2012, inudgeyou.com 2014). The Organisation for Economic Development and Cooperation (OECD) has published a Consumer Policy Toolkit that recommends a number of initiatives rooted in behavioral findings (OECD 2010). In the European Union, the Directorate-General for Health and Consumers has also shown the influence of psychology and behavioral economics (DG SANCO 2010). Private organizations, notably including the European Nudge Network, are producing creative and imaginative uses of behavioral insights to promote a variety of environmental, health-related, and other goals (see inudgeyou.com 2014, see also greeNudge.no 2014). Emphasizing relevant psychological work, Singapore has initiated a large number of reforms in this domain (Low 2011).

There has been particular interest in using the relevant research in the areas of poverty and development (Mullainathan 2007, Banerjee \& Duflo, 2012), with considerable attention from the World Bank. Behaviorally informed approaches might help combat corruption and inefficiency, and also make existing programs more effective, in part by combating low take-up rates and improving well-motivated but counterproductive initiatives that are not alert to human psychology (cf. Mullainathan and Shafir 2013).

A central reason for the mounting influence of psychology is that it has complemented, and in some ways complicated, the conventional emphasis on the importance of material incentives. No one denies that actual and perceived costs and benefits matter. But the word "perceived" is important; it is necessary to understand how people will actually respond to material incentives. Sometimes their responses turn out to surprise policymakers. If people do not pay attention to an incentive, it may have little or no impact, even if it is large in economic terms (cf. Chetty et al. 2012), and inertia, inattention, and procrastination might render an incentive irrelevant. Consider, for example, the fact that large numbers of people do not refinance their mortgages, even though they have a great deal to gain from doing so (Keys et al. 2014).

Officials are increasingly aware that they should explore the importance of the social environment, sometimes described as "choice architecture" (Thaler \& Sunstein 2008). Even when the material incentives seem small or nonexistent, changes in choice architecture can have large effects on outcomes (ibid.; Wansink 2014). When, for example, healthy foods are prominent and easily accessible, people are more likely to choose them; one study finds an 8 to 16 percent decrease in intake simply by making food more difficult to reach (as, for example, by varying its proximity by ten inches or altering the 
serving utensil) (Rozin et al. 2011). The problem of childhood obesity is, at least in part, a result of the easy availability of unhealthy foods (Wansink 2014). The same point - involving what is easily available and what commands attention -- bears on smoking, alcohol abuse, and even happiness, which has also been receiving official attention (Dolan 2014). When job candidates are evaluated together rather than independently, the incidence of sex discrimination is reduced, thus suggesting the possibility of nudges that would reduce discrimination of diverse kinds (Bohnet et al. 2012).

Psychologically informed initiatives often have major consequences. For example, automatic enrollment in savings programs can have far larger effects than significant economic incentives - a clear testimonial to the potential power of choice architecture and its occasionally larger effect than standard economic tools (Chetty et al. 2012). If people are asked to sign forms first rather than last - an especially minor change - the incidence of honesty might increase significantly (Shu et al. 2012). Default rules can have a significant impact in the environmental area, with large effects on public health (Sunstein \& Reisch 2014). Obesity can be significantly reduced by nudges (Wansink 2014); consider the important idea that "[b]ecoming slim by design is easier than trying to become slim by willpower" (id.). There is even a possibility of increasing happiness "by design," at least if we focus on the overriding importance of where our attention is directed (Dolan 2014).

The catalogue of potentially effective choice-preserving interventions is large and growing. For example, it includes the following: (1) default rules (including automatic enrollment in various programs, involving education, health, food, and savings); (2) simplification (and perhaps radical simplification) of existing requirements; (3) insistence on active choosing; (4) reminders (perhaps by email or text message); (5) priming (perhaps by emphasizing some relevant feature of the situation or some aspect of people's identity); (6) eliciting implementation intentions or commitments ("do you plan to vote?"); (7) uses of social norms ("most people plan to vote"); (8) order effects (what do people see first?); (9) use of loss aversion ("you will lose \$X if you do not use energy conservation techniques," or alternatively, a very small tax); (10) increases in ease and convenience ("make it easy" is frequent behavioral advice); (11) framing ("10 percent fat" rather than "90 percent fat-free"); (12) disclosure (as in calorie counts or traffic lights systems for food); (13) warnings, graphic or otherwise; (14) cooling off periods; (15) precommitment strategies (consider Save More 
Tomorrow or Give More Tomorrow or Lose Weight Tomorrow); (16) automatic enrollment combined with precommitment; (17) uses of colors and fonts, (18) plain language; (19) efforts to attract or reduce attention, including through product or attribute placement (for example, through cafeteria design, Wansink 2014); (20) engaging in moral suasion, attempting to make certain activities fun, or triggering a sense of responsibility ("Don't Mess With Texas"); (21) checklists (as for administrators or doctors); (22) prompted choice (where people are asked a question without being required to answer); (23) simplified active choosing (where people are asked whether they want to choose or instead to rely on a default rule); (24) enhanced or influenced active choosing (for example, asking people to choose but using order effects or loss aversion to influence choices); (25) efforts to make contexts, situations, and policies more easily navigable, through pointers and guides (consider the GPS); and (26) paperwork reduction (including prepopulation of forms, elimination of forms, and reductions in questions). (See Appendix for a somewhat longer one-page list.) As the fuel economy example indicates, and importantly, it is also possible to favor some mandates or bans on psychological or behavioral grounds, at least if the welfare calculus so suggests (Bubb and Pildes 2014, Sunstein 2014).

Of course a great deal remains to be learned, especially about the effects of reforms on large populations, across cultures, and on potentially distinctive subpopulations. One of the most important developments in recent years has been the emphasis on rigorous testing of policies to identify their effects. At official levels, randomized controlled trials are growing in popularity (Sunstein 2013a), and they are often essential. But even at this stage, psychological research suggests six concrete lessons for policy:

(1) default rules are an especially promising tool, combining effectiveness with preservation of freedom of choice;

(2) in some cases, required active choosing may be preferable to default rules insofar as it counteracts the problem of inertia while also responding to the risk that policymakers may err if they rely on default rules;

(3) simplification often pays large dividends, in part because it reduces burdens on people's "bandwidth," (Mullainathan \& Shafir 2013), potentially increasing uptake of important programs and reducing serious burdens on ordinary people (especially but not only the poor); 
(4) policymakers can fruitfully enlist social norms in the service of public goals, because people are more likely to engage in desirable behavior if they are informed that most people engage in desirable behavior.

(5) disclosure can be helpful, but only if it is psychologically informed (Loewenstein et al. 2014b); and cognitive accessibility (sometimes described as salience) greatly matters, in part because people have limited attention (Dolan 2014).

Notwithstanding these lessons, it is important to acknowledge that the very idea of a Council of Psychological Advisers, or of psychologically informed policymaking, might produce political concern, possibly even alarm. Indeed, prominent uses of behavioral science have sometimes proved controversial (Rebonato 2012; Sunstein 2013a). The goal of increasing simplification and navigability is unlikely to raise serious concerns, but any form of paternalism might run into real objections (for very different perspectives, see Rebonato, 2012, Conly, 2012). As we shall see, transparency and openness are exceedingly important. The idea of behaviorally informed policymaking also raises significant institutional challenges. A concluding section briefly explores the relevant concerns and issues of paternalism and institutional design (see also Thaler \& Sunstein 2008, Rebonato 2012).

\section{DEFAULT RULES}

In many contexts, it is possible to promote public goals with sensible default rules that preserve freedom of choice and that might help to avoid the rigidity, cost, and unintended adverse consequences of mandates and bans (Thaler \& Sunstein 2008, Sunstein \& Reisch $2014)$. Because of their unique importance, I devote special attention to default rules here (for interesting applications, see Wansink 2014, Dolan 2014).

\section{A. Automatic Enrollment and Default Rules: Examples}

\section{Savings.}

In the United States, employers have long asked workers whether they want to enroll in $401(\mathrm{k})$ plans; under a common approach, the default rule is nonenrollment. Even when enrollment is easy, the number of employees who enroll, or opt in, has sometimes been relatively low (Madrian \& Shea 2001, Gale et al. 2009). A number of employers have responded by changing the default to automatic 
enrollment, by which employees are enrolled unless they opt out. The results are clear: significantly more employees end up enrolled with an opt-out design than with opt-in (Gale et al. 2009, Chetty et al. 2012). This is so even when opting out is easy. Importantly, automatic enrollment has significant benefits for all groups, with increased anticipated savings for Hispanics, African Americans, and women in particular (Orszag \& Rodriguez 2009, Papke et al. 2009, Chiteji \& Walker 2009). As noted, default rules can have much larger effects than significant tax incentives (Chetty et al. 2012) - a genuine puzzle from the standpoint of standard economics, but a far less surprising finding from the standpoint of psychology.

The Pension Protection Act of 2006 (PPA) (Pension Protection Act 2006) draws directly on these findings by encouraging employers to adopt automatic enrollment plans. The PPA does this by providing nondiscrimination safe harbors for elective deferrals and for matching contributions under plans that include an automatic enrollment feature, as well as by providing protections from state payrollwithholding laws to allow for automatic enrollment. Building on these efforts, President Obama directed the Internal Revenue Service (IRS) and the Treasury Department to undertake initiatives to make it easier for employers to adopt such plans (Obama 2009a, IRS 2009). As a result of both private and public action, informed by psychological research, automatic enrollment (along with automatic escalation, sometimes under the rubric of "Save More Tomorrow") has been growing rapidly (Benartzi \& Thaler 2013, Benartzi 2012).

Automatic enrollment has been used in many other nations. In 2007, New Zealand introduced the idea of "KiwiSaver," whose principal feature is auto-enrollment. Within four years, the result of the initiative was to increase pension coverage by nearly 50 percentage points (Lunn 2014). As noted, similar success has been found in the United Kingdom, and Denmark has also experienced substantial increases as a result of automatic enrollment (Chetty et al. 2012).

\section{Green energy.}

Many people have been interested in increasing consumers' use of "green energy"--energy sources that do not significantly contribute to air pollution, climate change, and other environmental problems. While such energy sources are available in many places, relatively few people choose them (notwithstanding the fact that in response to questions, Pichert \& Katsikopoulos (2008) found that many say that they would do so). The point certainly holds in Germany (ibid.). Nonetheless, two 
communities in that nation have long shown strikingly high levels of green energy use - in a recent period, well over 90 percent (ibid.). This is a dramatic contrast to the level of participation in green energy programs in other German towns, which was in the relevant time period around one percent (ibid.). The reason for the difference is that in those two communities, people are automatically enrolled in green energy programs, and they have to opt out.

In many contexts, environmental and energy-related goals might be, and to some extent are being, promoted through green default rules (Sunstein \& Reisch 2014). To take a small but revealing example: A double-sided default rule for printers is likely to save a great deal of paper, and indeed to have a larger effect than a significant tax on paper use (for citations and discussion, see Sunstein \& Reisch 2014).

3. Health care.

A provision of the Affordable Care Act requires employers with over two hundred employees automatically to enroll employees in health care plans, while also allowing employees to opt out (Patient Protection and Affordable Care Act 2010). Another provision of the Act is called the Community Living Assistance Services and Supports Act (CLASS Act) (CLASS Act 2010); this provision creates a national voluntary long-term insurance program. The Act provides for an automatic enrollment system, whereby employers enroll employees in the program unless they opt out (CLASS Act 2010). In addition, the Act contains an automatic payroll deduction system for the payment of premiums (CLASS Act 2010).

In 2010, the Centers for Medicare \& Medicaid Services (CMS) provided guidance to states via a State Health Official (SHO) letter (CMS 2010). In cases where states are able to obtain all the information necessary to determine eligibility, the new option permits States automatically to enroll and renew eligible children in Medicaid or Children's Health Insurance Program (CHIP). This approach allows states to initiate and determine eligibility for Medicaid or CHIP without a signed Medicaid or CHIP program application.

\section{Consumer rights.}

In a number of areas, policymakers have attempted to protect consumer rights through regulation of default rules. Recall the action of the Federal Reserve Board, forbidding automatic enrollment in overdraft protection programs (Willis 2013). Under the Credit Card Accountability Responsibility and Disclosure Act of 2009, companies 
are forbidden to impose fees on cardholders who go over their credit limit unless cardholders agree to opt in to authorize that practice (ibid.). In Europe, Article 22 of the 2011 Consumer Rights Directive explicitly bans the use of pre-filled boxes in online payment forms: "If the trader has not obtained the consumer's express consent but has inferred it by using default options which the consumer is required to reject in order to avoid the additional payment, the consumer shall be entitled to reimbursement of this payment." (European Parliament \& Council of the EU 2011; Lunn 2014).

\section{School meals.}

Under federal law, poor children are eligible for free lunches and breakfasts at school. Unfortunately, many poor families have failed to sign up for the relevant programs, perhaps because of the burdens involved in doing so - a special problem in light of the limited cognitive bandwidth of the poor (Mullainathan \& Shafir 2013). In response, the National School Lunch Act (Healthy, Hunger-Free Kids Act 2010) authorizes and promotes "direct certification" of eligibility, thus reducing complexity and introducing what is a form of automatic enrollment.

Under the program, children who are eligible for benefits under certain programs are "directly eligible" for free lunches and free breakfasts, and hence do not have to fill out additional applications (Healthy, Hunger-Free Kids Act 2010). In 2011, the USDA issued an interim final rule that is providing up to 270,000 children with school meals (USDA 2011a). The total number of school children now enrolled in the "direct certification" program exceeds two million (USDA 2013).

6. Electronic rather than paper statements.

In 2010, the Department of Homeland Security changed the default setting for payroll statements to electronic from paper, thus reducing costs (Orszag 2010). Changes of this kind may save significant sums of money for both private and public sectors.

\section{B. Explanations}

Why do default rules have such large effects, even when the cost of departing from them is close to zero? A great deal of psychological and behavioral research has attempted to answer that question (Gale et al. 2009, Dinner et al. 2011, Carroll et al. 2009, Johnson \& Goldstein 2013, Sunstein 2013b). There appear to be three contributing factors (Johnson \& Goldstein 2013, Sunstein 2015b). The first factor involves 
what might be taken to be an implicit endorsement of the default rule (McKenzie et al 2006). Many people appear to conclude that the default was chosen for a reason; they believe that they should not depart from it unless they have particular information to justify a change.

The second factor involves inertia and procrastination. To alter the effect of the default rule, people must make an active choice to reject the default. They have to expend some effort and in this sense incur some costs (even if those costs are purely psychological). In view of the power of inertia and the tendency to procrastinate, people may simply continue with the status quo, thus avoiding what might be a kind of "effort tax" (Johnson \& Goldstein 2013). It follows that selfconsciously and well-chosen default rules by individuals, or by private or public institutions, can operate as commitment devices; consider, for example, a default rule in favor of monthly transfer of money into a savings account, or in favor of savings for retirement.

Third, the default rule might establish the reference point for people's decisions. The established reference point has significant effects because people dislike losses from that reference point - the psychological finding of "loss aversion" (Sunstein 2013b). If, for example, the default rule favors energy-efficient light bulbs, then the loss (in terms of reduced efficiency) may loom large and there will be a tendency to continue with energy efficient light bulbs. But if the default rule favors less efficient (and initially less expensive) light bulbs, then the loss in terms of upfront costs may loom large, and there will be a tendency to favor less efficient light bulbs.

It follows that default rules may not "stick" when the relevant population has strong contrary preferences. For example, a study in the United Kingdom found that most people rejected a savings plan with an unusually high default contribution rate (12 percent of before-tax income) (Beshears et al. 2010). Only about 25 percent of employees remained at that rate after a year, whereas about 60 of employees remained at a lower default contribution rate (Beshears et al. 2010). One implication is that "extreme" defaults are less likely to stick; another implication, based on the lower incomes of those who stayed with the default, is that default rules may be more influential for lowincome workers than for their higher-earning counterparts (Beshears et al. 2010).

A related finding is that workers were not much affected by a default allocation of a fraction of their tax refund to US savings bonds, apparently because such workers had definite plans to spend their refunds (Bronchetti et al. 2013). A general lesson is that default rules will have a weaker effect, and potentially no effect, when the relevant 
population has a strong preference for a certain outcome. If the default setting on thermometer is set down by 1 degree $C$ in winter, significant economic and environmental savings might be expected; but if it is set down by 2 degree $C$, the savings might be lower, because people will reject the default (Brown et al. 2013). The implication, both large and profound, can be described in a slogan: Defaults will stick unless they make people too cold.

\section{Risks.}

Needless to say, default rules can be badly chosen or misused by private and public institutions alike. A central question -- at the intersection of psychology, economics, and policy -- is whether the relevant rule is one that informed choosers would select (Sunstein $2015 b$ ). Both standard economics and psychology identify reasons that markets might produce harmful default rules, at least when they are not visible or easily accessible to consumers. Self-interested actors might promote default rules that benefit them rather than choosers, and such rules might nonetheless stick.

The Federal Trade Commission (FTC) has expressed serious concerns about "negative option marketing," which occurs when those who accept a "free" product are automatically enrolled in a plan or program that carries a monthly fee (unless they explicitly opt out) (16 C.F.R. § 425; FTC 2009). In some cases, negative option marketing has the unfortunate effect of using a default rule to exploit the tendency toward inertia in a way that is harmful to people's welfare; it is easy to imagine both private and public analogues (consider, for example, an automatic enrollment policy that puts an unreasonably large amount of salary into savings).

To evaluate the use of automatic enrollment, the particular circumstances certainly matter. If automatic enrollment is not made transparent to those who are enrolled, it can be considered a form of manipulation, and the problem is worse if it is not in their long-term interest.

\section{Personalization.}

Some default rules apply to all of the relevant population, subject to the ability to opt out. Other default rules are personalized, in the sense that they draw on available information about which approach best suits individuals in the relevant population (Sunstein 2013b). A personalized default might be based on geographical or demographic 
variables; for example, income and age might be used in determining appropriate default rules for retirement plans. Alternatively, a personalized default might be based on people's own past choices to the extent that they are available. Indeed, large data sets might be enlisted to design personalized default rules for individuals, with or without attention to their own past choices.

An advantage of personalized default rules is that they may well be more accurate than "mass" default rules. As technology evolves, it should be increasingly possible to produce personalized defaults, based on people's own choices and situations, and likely to be far more accurate than more general ones. There will be excellent opportunities to use default rules to promote people's welfare. To be sure, any such rules must respect the applicable laws, policies, and regulations involving personal privacy and should avoid unduly crude proxies.

\section{Requiring Active Choosing}

Sometimes public officials and outside observers do not like default rules, on the ground that they can stick, and might be seen to be manipulative (Rebonato 2012). We need to learn much more about people's reactions to such rules (Loewenstein et al. 2014a; Brehm \& Brehm 1981). To the extent that the concerns are warranted, an alternative approach, sometimes worth serious consideration, is to avoid any default rule and to require active choices (Carroll et al. 2009, Sunstein 2013b).

Under this approach, people are required to make an actual choice among the various options; they are not defaulted into any particular alternative. With respect to savings and health care, for example, an employer might reject both opt-out and opt-in and simply require employees to indicate their preferences. Evidence suggests that active choices result in far higher levels of savings than a default rules that requires people explicitly to opt in (Carroll et al. 2009).

There is a strong psychological argument for requiring active choosing (Sunstein 2015a). If inertia and procrastination are playing a significant role, then active choosing may be better than opt-in, through which people end up with outcomes that they would not prefer if they were to make a choice. In such circumstances, active choosing increases the likelihood that people will end up with their preferred outcomes. In addition, active choosers take responsibility for their choices, and their sense of responsibility might have significant effects on their own future (for example, in making them more committed to taking care of their health) and also on family members (to whom it 
might greatly matter, in the context of end-of-life care, that the relevant decision was made actively rather than passively).

Active choosing might also be preferred when public officials lack relevant information, so that the chosen default rule might be harmful (Rebonato 2011; Sunstein 2013b; Sunstein 2015a). This is an especially important point. If officials are inadequately informed, and if the default rule is no better than a guess, that rule might lead people in the wrong direction. The same point argues against a default rule when self-interested private groups have managed to call for it, even though it is not in the interest of those on whom it is imposed. Public choice theorists, emphasizing the power of such groups, might be skeptical of official default rules for that reason (Rebonato 2011). Active choosing is much less risky on these counts.

As compared with either opt-in or opt-out, active choosing can also have significant advantages when the relevant group has a great deal of diversity, so that a single approach is unlikely to fit variable circumstances. In such contexts, a default rule may also be harmful, because the power of inertia, or the force of suggestion, may mean that many people will end up in a situation that is not in their interest. For this reason, active choosing may be better.

On the other hand, active choosing can have significant disadvantages. A serious problem is that in situations of unfamiliarity or great complexity, in which people lack information or experience, active choosing may impose unjustified or excessive burdens (Thaler \& Sunstein 2008, Sunstein 2013b). These burdens should not be underestimated; they can take a serious toll (Mullainathan and Shafir 2013). They include not only the time (and potentially resources and emotion) required for people to obtain relevant information and to make the choice, but also the resources that must be expended on ensuring that they actually make it. As compared with a default rule, active choosing increases the costs of decisions, possibly significantly. It also might increase errors, possibly significantly, if the area is unfamiliar and confusing, and if people will choice poorly. In such situations, opt-in or opt-out might produce better outcomes for people.

In the private sector, default rules (for cell phones, computers, automobiles, and much more) are often in people's interests, and active choosing would impose unnecessary burdens. When public officials have good reason for confidence that a particular default rule will fit with the informed preferences of the relevant group, and thus promote its interests, it may be preferable to select that default rule rather than to require active choosing (Sunstein 2015b). Personalized default rules, by virtue of their accuracy, can have particular virtues on this count. 


\section{Simplification}

\section{A. Complexity, Take-Up Rates, and the Bandwidth Problem}

A great deal of psychological work demonstrates that complexity can have serious unintended effects (including indifference, delay, and confusion), potentially undermining policy goals by reducing compliance or by decreasing the likelihood that people will benefit from various policies and programs (Mullainathan \& Shafir 2013). Complex forms can be especially harmful on this count. The psychological effects of complexity, in discouraging participation, are often insufficiently appreciated by policymakers, who might be able to achieve that same goal through simplification as through large-scale expenditures.

Consider two examples, both with significant policy implications. (1) Simplification of a complex form for financial assistance for college can have the same effect, in terms of increasing program participation, as a significant boost in economic incentives - in the thousands of dollars (Bettinger et al. 2009). (2) Homeowners can save a great deal of money from refinancing, but in the United States, people have recently lost $\$ 5.4$ billion as a result of failure to refinance, largely because of the interaction between human psychology and relatively complex requirements (Keys et al. 2014).

A particular area for further study involves the effects of cognitive load, which imposes a kind of "bandwidth tax," with particularly harmful effects on poor people (Mullainathan \& Shafir 2013). In the United States, the Paperwork Reduction Act has long been designed to reduce form-filling burdens, but policymakers are only starting to see the connection between those burdens and the bandwidth problem. If psychologically informed policymakers can increase participation through simplification, or even achieve the same goals that could otherwise be achieved only through large expenditures, there is an evident attraction to simplification (Mullainathan \& Shafir 2013; Sunstein 2013a). Note in this regard that when people stand to gain significant amounts of money from redeeming certain coupons or certificates, they are unrealistically optimistic about the likelihood that they will take the trouble to mail in the relevant forms - and that the only intervention that appears to work is to make redemption easier (Letzler and Tasoff 2013). As the authors put it, "everyone believes in redemption," but whether the possibility will be cashed out, so to speak, only if it is simple to do so (ibid.). 
In recognition of the underlying psychological and behavioral research, a series of steps have been taken toward simplifying the Free Application for Federal Student Aid (FAFSA), reducing the number of questions through skip logic (a survey method that uses previous responses to determine subsequent questions) and allowing electronic retrieval of information (Office of Management and Budget 2010). Use of a simpler and shorter form is accompanied by an initiative to permit online users to transfer data previously supplied electronically in their tax forms directly into their FAFSA applications.

These steps are intended to simplify the application process for financial aid and thus to increase access to college; there is good reason to believe that such steps will enable many students to receive aid for attending college when they previously could not do so. On FAFSA, a great deal remains to be done; a very short form, perhaps just twopage, might be sufficient. Related steps might be taken in many other domains, especially those designed to help poor people, where wellintended and seemingly innocuous paperwork burdens can be counterproductive (Mullainathan \& Shafir 2013).

The Department of Treasury (2008) has also launched an important initiative in the domain of Social Security and Supplemental Security Income: the "Direct Express" card program. Many people are now automatically receiving their money via a prepaid debit card. This measure increases, at the same time, both convenience and accuracy, thus reducing paperwork and costs. It provides particular help for those who lack bank accounts. Other programs might build on this approach by considering the choice between an opt-in and opt-out design and simplifying people's choices. Some such programs might be designed to help those without bank accounts, by giving them such accounts or the functional equivalent.

In 2011, the Office of Management and Budget drew on psychological research in calling for simplification, focusing in particular on small business and benefit programs (Sunstein 2011). The request drew particular attention to the potential harms of complexity (in the context of financial products, see Bar-Gill 2012), noting that

the process of renewing or applying for benefits can be timeconsuming, confusing, and unnecessarily complex, thus discouraging participation and undermining program goals. Sometimes agencies collect data that are unchanged from prior applications; in such circumstances, they might be able to use, or to give people the option to use, pre-populated electronic forms (Sunstein 2011). 
And indeed, there is reason to believe that imperfect take-up of existing benefit programs, including those that provide income support, is partly a product of behavioral factors such as procrastination and inertia (Keys et al. 2014; cf. Letzler and Tasoff 2013, Mullainathan \& Shafir 2013). It follows that efforts to increase simplicity, including automatic enrollment, may have substantial benefits (Mullainathan \& Shafir 2013). In the United Kingdom, significant results have been obtained in increasing payments of fines, largely by making it easier and more convenient for people to do so, and by sending reminders by telephone and text (Lunn 2014).

The United Kingdom's Office of Gas and Electricity Markets (OFGEM) has undertaken a number of initiatives to simplify regulatory burdens on both industry and consumers. Among these is a proposal to simplify how energy retailers provide information about rate tariffs to consumers, with the goal of enhancing consumer choice (Lunn 2014). One reason for the initiatives was that in the aftermath of deregulation of energy markets, many consumers made poor choices, and in some cases remained with costly tariffs with incumbent suppliers (ibid.). OFGEM hopes to promote informed choices as a result of simplification.

\section{B. Structuring Choices}

In the traditional view, having more choices helps, and never harms, consumers or program participants. This view is based on the reasonable judgment that, if an additional option is not better than existing options, people will simply not choose it. In general, more choices are indeed desirable, but an increasing body of research offers certain potential qualifications, especially in unusually complex situations (Schwartz 2004; Sethi-Iyengar et al. 2004). For example, there is some evidence that enrollment may decline, (Sethi-Iyengar et al. 2004), and asset allocations may worsen, (Iyengar \& Kamenica 2010 ) as the menu of investment options in a 401(k) plan expands.

Responding to this general problem in the context of prescription drug plans, where the cognitive challenges in program selection can be especially severe and indeed overwhelming (Thaler \& Sunstein 2008), the United States government has taken strong steps to eliminate unhelpful and unnecessary complexity (Gruber \& Abaluck 2011). The Centers for Medicare and Medicaid Services' Medicare Part D program rules, adopted in 2011, require sponsors to ensure that when they provide multiple plan offerings, those offerings have meaningful differences. The rules also eliminate plans with persistently low enrollments, on the ground that those plans increase the complexity of choices without adding value. There is no question that the changes in 
these rules were informed by the relevant psychological research about the adverse effects of complexity.

\section{SOCIAL NORMS AND CONFORMITY}

Psychologists have emphasized the importance of social practices and norms, which have a significant influence on individual decisions. Because people take the behavior of others as information about what it is normal or appropriate to do, people might well imitate that behavior (Cialdini et al. 2006). In fact social norms can operate as the equivalent of defaults, with observed choices spurring imitative behavior (Huh et al. 2014).

If, for example, people learn that they are using more energy than similarly situated others, their energy use may decline-saving money while also reducing pollution. The same point applies to health-related behavior. It has long been understood that people are more likely to engage in healthy behavior if they live or work with others who so engage. And if people are in a social network with other people who are obese, they are significantly more likely to become obese themselves. The behavior of relevant others can provide valuable information about sensible or appropriate courses of action. Informational cascades are a possible consequence, as people rely on, and thus amplify, the informational signals produced by the actions of their predecessors (Hirschleifer 1995). Similarly, those actions can provide information about what others will approve and disapprove.

Psychological research suggests that efforts to use social comparisons can alter decisions and significantly reduce economic and environmental costs. In the private sector, these points are being put to creative use. Opower, an American company that makes impressive use of behavioral economics, specializes in providing people with social comparisons, above all through its innovative Home Energy Report. Opower's reports have had a major effect. Over four million households now receive Home Energy Reports, and they are saving people hundreds of millions of dollars as a result. (See opower.com for details.) These and related interventions can save consumers a great deal of money and also reduce pollution.

These points have implications for many domains. For example, efforts to increase tax collection, and to reduce violations, can enlist social norms (Hallsworth et al. 2014). In the first of two careful experiments from the U.K. Behavioural Insights Team, Hallsworth and his colleagues sent letters to more than 100,000 citizens in 2011. All of the letters noted that the recipients had not yet made correct tax payments, but there were different versions of what followed that 
reminder. The first said: "Nine out of ten people pay their taxes on time." The second version said: "Nine out of ten people in the UK pay their taxes on time." The third said: "Nine out of ten people in the UK pay their taxes on time. You are currently in the very small minority of people who have not paid us yet." The fourth did not refer to social norms, but added this sentence: "Paying tax means we all gain from vital public services" such as the National Health Service, roads and schools.

The letters were exceedingly effective. Overall, those who received one of these letters were nearly four times more likely to pay their tax bill than those who did not. The most effective letter was the third: In less than a month, it produced $\$ 3.18$ million in additional revenue. If that letter had been used across the entire sample, it would have produced an additional \$18.9 million.

Hallsworth and his colleagues' second experiment involved nearly 120,000 taxpayers and more than a dozen different letters. Some of the letters referred to a general norm about existing practices: "The great majority of people in the UK pay their tax on time." Other letters were more specific: "The great majority of people in your local area pay their tax on time" or "Most people with a debt like yours have paid it by now."

Some of the letters referred to what people in the U.K. think taxpayers should do: "The great majority of people agree that everyone in the UK should pay their tax on time," or "Nine out of ten people agree that everyone in the UK should pay their tax in time." Some of the letters emphasized that people could save money by paying now rather than later: "We are charging you interest on this amount."

With this experiment, Hallsworth and his colleagues replicated their earlier finding: "Norm" messages have a large impact. Finally, highlighting a penalty that would increase over time made it more likely that people would pay. Within a period of about three weeks, Hallsworth and his colleagues were able to generate about $\$ 15.24$ million in additional tax revenue. Note that letters of this sort are not expensive to produce and send, so the benefits of the intervention were easily justified. In other contexts, reminders have had significant effects (Lunn 2014); they appear to work best if they are personalized (id.).

In recent decades, smoking and seat belt regulations appear to have worked hand in hand with emerging social norms, helping to reduce deaths and injuries. In the context of seat belt usage in the United States, there has been a dramatic change in behavior, with an increase in a few decades from usage rates under 15 percent to usage rates over 70 percent, in significant part as a result of social norms that 
operated in concert with regulatory changes. In some domains, social norms have helped to promote compliance with law even without active enforcement. Public-private partnerships can be especially important in this domain, as those in the private sector emphasize norms that increase compliance with law and promote safer choices.

Consider as well the problem of distracted driving. In 2009, President Obama (2009b) issued an executive order that bans federal employees from texting while driving. Such steps can help promote a social norm against texting while driving, thus reducing risks. This same approach-emphasizing social norms-might be applied in many domains. In the domain of childhood obesity, for example, a social norm in favor of healthy eating and proper exercise could produce significant health benefits. Here, as elsewhere, public-private partnerships can play a key role, with those in the private sector helping to spur emerging norms that promote better choices by and for children.

An understanding of social norms and conformity also helps to explain political polarization, in a way that can be relevant to political actors of all kinds. For example, social psychologists have explored the phenomenon of "group polarization," which means that people in deliberating groups tend to end up in a more extreme point in line with their predeliberation tendencies (Sunstein 2009). If members of one like-minded group (say, people who are left of center) speak with one another, and if members of another like-minded group (say, people who are right of center) speak only with one another, severe divisions might be expected. An understanding of group polarization thus casts light on political divisions in many democracies. It also helps explain why some groups become quite extreme, even prone to violence (Hardin 2002).

There are also implications for the problem of "groupthink," understood in the light of recent psychological findings, which help to show how institutions can elicit, or fail to elicit, important information (Sunstein \& Hastie 2015). A pressing challenge is to devise strategies, especially but not only within governments, to ensure against polarization and herding (ibid.). 


\section{DISCLOSURE}

\section{A. Actually Informing Choice}

\section{Examples.}

Many programs are based on a judgment that information disclosure can be a useful regulatory tool, replacing or complementing other approaches. There is much more both to learn and to do; in this area in particular, existing knowledge is inadequate, and many gaps remain to be filled (Bubb 2014, Loewenstein 2014b). But in numerous cases, disclosure requirements have been psychologically informed, especially since the early 2000s. Central examples include legislative efforts to require disclosure of the potential savings from energy efficiency and of information that bears on health. Some of these initiatives have drawn directly from psychology and behavioral science, emphasizing the importance of plain language, clarity, and simplicity, and of ensuring that any advice is "actionable."

a) Nutrition. In the domain of nutrition, a number of disclosure requirements are in place. To take just one example, a final rule was issued in 2011 by the US Department of Agriculture (USDA), requiring provision of nutritional information to consumers with respect to meat and poultry products. Nutrition facts panels must be provided on the labels of such products. Under the rule, the panels must contain information with respect to calories and both total and saturated fats (9 C.F.R. § 317.309).

The rule clearly recognizes the potential importance of the psychological phenomenon of framing. If a product lists a percentage statement such as " $80 \%$ lean," it must also list its fat percentage. This requirement should avoid the confusion that can result from selective framing; a statement that a product is 80 percent lean, standing by itself, makes leanness salient, and may therefore be misleading. As noted, the Food and Drug Administration has proposed new rules to govern nutrition facts panels, and those rules explicitly refer to the behavioral literature, which informs the content of the proposals (US FDA 2014a).

b) Credit cards and consumer financial protection. Behavioral science played a significant role in informing the Credit Card Accountability, Responsibility, and Disclosure Act of 2009 (Credit CARD Act 2009), which is designed in large part to ensure that credit card users are adequately informed. Specifically, the Act prohibits an increase in annual percentage rates (APR) without forty-five days' notice, prohibits the retroactive application of rate increases to existing 
balances, and also requires clear notice of the consumer's right to cancel the credit card when the APR is raised.

The Act also requires a number of electronic disclosures of credit card agreements. Specifically, it requires that (1) "[e]ach creditor shall establish and maintain an Internet site on which the creditor shall post the written agreement between the creditor and the consumer for each credit card account under an open-end consumer credit plan"; (2) "[e]ach creditor shall provide to the Board, in electronic format, the consumer credit card agreements that it publishes on its Internet site"; and (3) the "Board shall establish and maintain on its publicly available Internet site a central repository of the consumer credit card agreements received from creditors pursuant to this subsection, and such agreements shall be easily accessible and retrievable by the public" (Credit CARD Act 2009).

Evidence suggests that the Act has saved consumers over $\$ 12$ billion annually. Moreover, one small nudge - requiring disclosure of the interest savings from paying off balances in 36 months rather than only making minimum payment - has saved consumers over $\$ 170$ million annually (Agarwal et al. 2013).

More generally, the Consumer Financial Protection Bureau has, as one of its central goals, the design of disclosure policies that will actually inform choices, as captured in the slogan, "know before you owe." The CFPB has taken steps to simplify disclosure for student loans, credit cards, and mortgages. In the process, it has taken careful account of psychological and behavioral research about the harmful effects of complexity (Lunn 2014).

c) Health care. The Patient Protection and Affordable Care Act of 2010 (Affordable Care Act) contains a large number of disclosure requirements designed to promote accountability and informed choice with respect to health care. Indeed, the Affordable Care Act is, in significant part, a series of disclosure requirements, many of which are meant to inform consumers, and to do so in a way that is alert to psychological findings. Under the Act, a restaurant that is part of a chain with twenty or more locations doing business under the same name is required to disclose calories on the menu board (on the empirical complexities and the mixed evidence see Loewenstein et al. 2014 b). Such restaurants are also required to provide in a written form (available to customers upon request) additional nutrition information pertaining to total calories and calories from fat, as well as amounts of fat, saturated fat, cholesterol, sodium, total carbohydrates, complex carbohydrates, sugars, dietary fiber, and protein (Affordable Care Act 2010). 
In a similar vein, $\S 1103$ of the Act calls for "[i]mmediate information that allows consumers to identify affordable coverage options." It requires the establishment of an internet portal for beneficiaries to easily access affordable and comprehensive coverage options, including information about eligibility, availability, premium rates, cost sharing, and the percentage of total premium revenues spent on health care, rather than administrative expenses.

Implementing a provision of the Affordable Care Act, the Department of Health and Human Services (HHS) finalized a rule to require insurance companies to provide clear, plain language summaries of relevant information to prospective customers. The rule includes basic information, including the annual premium, the annual deductible, a statement of services that are not covered, and a statement of costs for going to an out-of-network provider (Healthcare.gov 2011).

d) Smart disclosure. In the United States, psychologically informed initiatives have focused on the idea of "smart disclosure," which is designed to help consumers know about their own choices (Kamenica et al. 2011). The basic idea is that it is costly for consumers to obtain that information, in part as a result of inertia, and hence the information should be made available in downloadable, machinereadable formats (Sunstein 2011). In the United Kingdom, the "midata" initiative aspires to give consumers more access to their consumption data, with the goal of allowing members of the public, among other things, to analyze their data via software applications and use to improve their decision-making (Lunn 2014; https://www.gov.uk/government/policies/providing-betterinformation-and-protection-for-consumers/supportingpages/personal-data). Under the Enterprise and Regulatory Reform Act 2013, the government has the authority to compel businesses to release consumer data; to date this has not been done, and the government is hoping for businesses to release their data voluntarily.

It should be clear from this brief survey that the range of recent disclosure requirements is very wide. Such approaches have considerable promise, though to a substantial degree, the jury is still out on their effects (Bubb 2014, Loewenstein et al. 2014b).

2. How, not only whether.

As psychologists have emphasized, disclosure as such may not be enough; regulators should devote care and attention to how, not only whether, disclosure occurs (Loewenstein et al. 2014b). Clarity and simplicity are often critical. In some cases, accurate disclosure of 
information may be ineffective if the information is too abstract, vague, detailed, complex, poorly framed, or overwhelming to be useful. In addition, emphasis on certain variables may attract undue attention and prove to be misleading. If disclosure requirements are to be helpful, they must be designed to be sensitive to how people actually process information.

A good rule of thumb is that disclosure should be concrete, straightforward, simple, meaningful, timely, and salient. If the goal is to inform people about how to avoid risks or to obtain benefits, disclosure should avoid abstract statements (such as, for example, of "healthy eating" or "good diet") and instead clearly identify the steps that might be taken to obtain the relevant goal (by specifying, for example, what specific actions parents might take to reduce the risk of childhood obesity).

In 2010, HHS emphasized the importance of clarity and cognitive accessibility in connection with its interim final rule entitled "Health Care Reform Insurance Web Portal Requirements," which "adopts the categories of information that will be collected and displayed as Web portal content, and the data we will require from issuers and request from States, associations, and high risk pools in order to create this content" (US Dep. HHS 2010). The preamble to the interim final rule is behaviorally informed in the sense that it is directly responsive to how people process information:

In implementing these requirements, we seek to develop a Web site (hereinafter called the Web portal) that would empower consumers by increasing informed choice and promoting market competition. To achieve these ends, we intend to provide a Web portal that provides information to consumers in a clear, salient, and easily navigated manner. We plan to minimize the use of technical language, jargon, or excessive complexity in order to promote the ability of consumers to understand the information and act in accordance with what they have learned.... [W] plan to provide information, consistent with applicable laws, in a format that is accessible for use by members of the public, allowing them to download and repackage the information, promoting innovation and the goal of consumer choice.

That web portal can be found at http://www.healthcare.gov/.

If not carefully designed, disclosure requirements can produce ineffective, confusing, and potentially misleading messages. Psychologically informed approaches are alert to this risk and suggest possible improvements. For instance, automobile manufacturers are 
currently required to disclose the fuel economy of new vehicles as measured by miles per gallon (MPG). This disclosure is useful for consumers and helps to promote informed choice. As the Environmental Protection Agency (EPA) has emphasized, however, MPG is a nonlinear measure of fuel consumption (US EPA 2009). For a fixed travel distance, a change from 20 to 25 MPG produces a larger reduction in fuel costs than does a change from 30 to $35 \mathrm{MPG}$, or even from 30 to 38 MPG. To see the point more dramatically, consider the fact that an increase from 10 to 20 MPG produces more savings than an increase from 20 to $40 \mathrm{MPG}$, and an increase from 10 to $11 \mathrm{MPG}$ produces savings almost as high as an increase from 34 to 50 MPG.

Evidence suggests that many consumers do not understand this point and tend to interpret MPG as linear with fuel costs (see Larrick and Soll 2008). When it occurs, this error is likely to produce inadequately informed purchasing decisions when people are making comparative judgments about fuel costs. For example, people may well underestimate the benefits of trading a low MPG car for one that is even slightly more fuel efficient. By contrast, an alternative fuel economy metric, such as gallons per mile, could be far less confusing. Such a measure is linear with fuel costs and hence suggests a possible way to help consumers make better choices.

A closely related finding is that because of the MPG illusion, consumers tend to underestimate the cost differences between lowMPG vehicles and tend to overestimate the cost differences between high-MPG vehicles (Allcott 2011). Recognizing the imperfections and potentially misleading nature of the MPG measure, and referring to the psychological literature, the Department of Transportation and EPA proposed in 2009 two alternative labels that are meant to provide consumers with clearer and more accurate information about the effects of fuel economy on fuel expenses and on the environment (US EPA 2009).

After a period of public comment, the Department of Transportation and EPA ultimately chose a new label to respond to the psychological and behavioral research (US EPA 2009). This approach calls for disclosure of the factual material included in the first option but adds a clear statement about anticipated fuel savings (or costs) over a five-year period. The statement of fuel savings (or costs) should simultaneously help counteract the MPG illusion and inform consumers of the economic effects of fuel economy over a relevant time period (US EPA 2009).

In a related vein, the USDA has abandoned the "Food Pyramid," used for decades as the central icon to promote healthy eating. The 
Pyramid has long been criticized as insufficiently informative; it does not offer people with any kind of clear "path" with respect to healthy diet. According to one critical account, "its meaning is almost completely opaque. ... To learn what the Food Pyramid has to say about food, you must be willing to decipher the Pyramid's markings.... The language and concepts here are so hopelessly abstracted from people's actual experience with food ... that the message confuses and demoralizes ..." (Heath \& Heath 2010).

Aware of these objections, and after an extended period of deliberation, the USDA (2011b) replaced the Pyramid with a new, simpler icon (the Food Plate), consisting of a plate with clear markings for fruit, vegetable, grains, and protein. The Food Plate is accompanied by straightforward guidance, including "make half your plate fruits and vegetables," "drink water instead of sugary drinks," and "switch to fatfree or low-fat (1\%) milk." This approach has the key advantage of informing people what to do, if they seek to have a healthier diet.

In some circumstances, the tendency toward unrealistic optimism (Sharot 2011 and Bar-Gill 2012) may lead some consumers to downplay or neglect information about statistical risks associated with a product or an activity. Possible examples include smoking and distracted driving. In such circumstances, disclosure might be designed to make the risks associated with the product less abstract, more vivid, and salient. For example, the Family Smoking Prevention and Tobacco Control Act of 2009` (Smoking Prevention Act) requires graphic warnings with respect to the risks of smoking tobacco, and the Food and Drug Administration (FDA) has finalized such warnings for public comment, with vivid and even disturbing pictures of some of the adverse outcomes associated with smoking. The compulsory warnings were invalidated in court (on free speech grounds), but the government has issued graphic warnings of its own, very possibly with significant effects.

\section{B. Psychology, Spurring Competition}

If disclosure requirements are straightforward and simple, they should facilitate comparison shopping and hence market competition. Drawing on social science research, the Treasury Department's account of financial regulation emphasizes the value of requiring that "communications with the consumer are reasonable, not merely technically compliant and non-deceptive. Reasonableness includes balance in the presentation of risks and benefits, as well as clarity and conspicuousness in the description of significant product costs and 
risks" (US Dep. Treasury 2009). The department's analysis goes on to say that one goal should be to

harness technology to make disclosures more dynamic and adaptable to the needs of the individual consumer.... Disclosures should show consumers the consequences of their financial decisions. ... [The regulator] should [ ] mandate or encourage calculator disclosures for mortgages to assist with comparison shopping. For example, a calculator that shows the costs of a mortgage based on the consumer's expectations for how long she will stay in the home may reveal a more significant difference between two products than appears on standard paper disclosures (US Dep. Treasury 2009).

In keeping with this theme, the Consumer Financial Protection Bureau is authorized to ensure that "consumers are provided with timely and understandable information to make responsible decisions about financial transactions" (Dodd-Frank Act 2010). The Bureau is also authorized to issue rules that ensure that information is "fully, accurately, and effectively disclosed to consumers in a manner that permits consumers to understand the costs, benefits, and risks associated with the product or service, in light of the facts and circumstances" (Dodd-Frank Act 2010).

To accomplish this task, the Bureau is authorized to issue model forms with "a clear and conspicuous disclosure that, at a minimum(A) uses plain language comprehensible to consumers; (B) contains a clear format and design, such as an easily readable type font; and (C) succinctly explains the information that must be communicated to the consumer" (Dodd-Frank Act 2010). In addition, the director of the Bureau is required to "establish a unit whose functions shall include researching, analyzing, and reporting on . . consumer awareness, understanding, and use of disclosures and communications regarding consumer financial products or services" and "consumer behavior with respect to consumer financial products or services, including performance on mortgage loans" (Dodd-Frank Act 2010). Note that new technologies make it possible to inform consumers of their own choices and usages, an approach that may be especially important when firms have better information than consumers do about such choices and usages.

In the same general vein, the Department of Labor issued a final rule requiring disclosure to workers of relevant information in pension plans. The rule is designed to require clear, simple disclosure of information about fees and expenses and to allow meaningful 
comparisons, in part through the use of standard methodologies in the calculation and disclosure of expense and return information (29 C.F.R. $\S 2550.404 a-5)$.

Yet another example is provided by a final rule of the Department of Education that promotes transparency and consumer choice with respect to for-profit education by requiring institutions to provide clear disclosure of costs, debt levels, graduation rates, and placement rates (US Dep. of Education 2010a). The rule states that relevant institutions must disclose, among other things, the occupations that the program prepares students to enter, the on-time graduation rate for students completing the program, the tuition and fees charged to students for completing the program within a normal time, the placement rate for students completing the program, and the median loan debt incurred by students who completed the program. These disclosures must be included "in promotional materials [the institution] makes available to prospective students" and be "[p]rominently provide[d] ... in a simple and meaningful manner on the home page of its program Web site" (34 C.F.R. § 668.6; US Dep. of Education, 2010b).

As noted, a great deal of work remains to be done on disclosure polices and in particular on when they are likely to be effective (Bubb 2014). But it is clear that if they are attuned to how people process information, they are far more likely to succeed than if they are not (ibid.; Loewenstein et al. 2014b).

\section{ATtention AND Cognitive AccessibiLity}

Psychological research suggests that it is often possible to promote policy goals by triggering people's attention and making certain features of a product or a situation more accessible to consumers. As a simple example of the importance of cognitive accessibility, consider alcohol taxes. There is evidence that when such taxes are specifically identified in the posted price, increases in such taxes have a larger negative effect on alcohol consumption than when they are applied at the register (Chetty et al. 2009; Finkelstein 2009). Of course incentives matter, but in order for them to matter, people must pay attention to them (Dolan 2014). Sensible policies, especially those that involve disclosure, are highly attentive to the importance of cognitive accessibility.

With respect to smoking prevention, for example, triggering attention to adverse health effects is a central purpose of disclosure requirements. In the context of smoking, graphic warnings are designed to be immediately accessible. Similarly, OSHA has issued a 
regulation requiring chemical manufacturers and importers to prepare labels for hazardous chemicals that include pictograms and signal words that can be easily understood by workers (29 C.F.R. §§ 1910, $1915,1926)$. Well-designed labels trigger attention; they make relevant factors salient to those who will see them. The significant consequences of convenience (return to the issue of obesity) can be seen as a close cousin of cognitive accessibility effects.

A similar point applies in the domain of energy efficiency. For many consumers, the potential savings of energy-efficient products may not be visible at the time of purchase, even if those savings are significant. The "Energy Paradox" refers to the fact that some consumers do not purchase energy-efficient products even when it is clearly in their economic interest to do so. Empirical work suggests that nonprice interventions, by making the effects of energy use more accessible, can alter decisions and significantly reduce electricity use There is evidence that such interventions can lead to private as well as public savings (Howarth et al. 2000). Consider, for example, the fact that energy costs are generally visible only once a month, when people are presented with the bill. Efforts to increase the cognitive accessibility of such costs, by displaying them in real time, can produce significant savings,

A related approach attempts to identify and refocus the frame through which people interpret information. There is some evidence that some consumers may not seriously consider annuities in retirement to insure against longevity risk-the risk that they will outlive their assets-because they do not fully appreciate the potential advantages of annuities (Brown 2007). One hypothesis is that some people evaluate annuities in an investment frame that focuses narrowly on risk and return (Brown et al. 2008). Looking through such a frame, consumers focus on the risk that they could die soon after annuity purchase and lose all of their money. Some evidence suggests that efforts to shift consumers into a consumption frame, which focuses on the end result of what they can consume over time, help consumers appreciate the potential benefits of annuities. The goal here is not to suggest a view on any particular approach to retirement; it is merely to emphasize that the relevant frame can increase cognitive accessibility.

\section{Politics, Paternalism, and Institutional Design}

Policymakers work, of course, amidst political constraints. No nation has a literal Council of Psychological Advisers, and at least one reason is political: Some citizens would be acutely suspicious of, and 
probably even alarmed by, the very idea. Is such a council helping government to manipulate its citizens, by exploiting human psychology to steer them in what it considers to be the right direction? Does government have any business using psychology to manipulate people (Rebonato 2011)? In some nations, including the United States, policies that incorporate psychology and behavioral economics have sometimes been controversial, and triggered adverse political reactions, in part because of the fear of manipulation on government's part (Sunstein 2013a). In many nations, active discussions are underway about whether use of the relevant research might be threatening to liberty or self-government.

\section{A. Campaigns and Governance}

We might make a distinction here. In political campaigns, of course, the key goal is to convince people to vote for one's candidate, and on that count, the use of psychology is well-established, not least as part of get-out-the-vote-strategies (Nickerson \& Rogers 2010). We know, for example, that if people are asked to describe their implementation intentions (their specific plans to execute their goals), they are more likely to act as planned; and if people's identity is triggered (for example, as voters), they are more likely to act in accordance with that identity (Nickerson \& Rogers 2010). In campaigns, most observers agree that it is legitimate to try to persuade people, and to date, the use of psychological research has not created serious negative reactions. Modern campaigns sometimes do have a kind of Council of Psychological Advisers, whether or not its members include people with psychological training, and any candidate would be well-advised to enlist what psychologists know.

In actual governing, however, the use of psychology can be more controversial, and the public reaction has sometimes been more skeptical. In the United States, the United Kingdom, and Germany, for example, some critics have seen the use of psychology and behavioral science, and the idea of "nudging," as an objectionable interference with freedom and dignity, and as showing a kind of disrespect for citizens.

\section{B. Problems, Not Theories}

One lesson for policymakers is that it is generally best if psychologically informed approaches are problem-driven and concrete, rather than theory-driven and abstract. In other words, it is preferable 
begin not with high-level theory but with identifiable problems obesity, poverty, consumer protection, crime, pollution -- and to consider which tools might help to reduce them. Social scientists, and academics more generally, often focus on the development and testing of theories, and on the generation of interesting and original ideas. In government, that approach is (to say the least) not ideal. In all probability, a Council of Psychological Advisers with that orientation would be promptly disbanded. It is far better to focus on current policies that are hurting people or not helping them, and to see how such policies might be improved -- or better still to identify serious problems that citizens are now facing, and to see how those problems might be addressed.

If a context is difficult to navigate, a reform that increases navigability would be a good idea (Norman 2013). Increased navigability, and decreased confusion, should not be controversial. If a nation faces a problem of low participation rates in pension plans, automatic enrollment is a potential solution, and it does not much matter whether psychology lies behind the policy. If the problem is one of low take-up, simplification ought not to be especially troubling (Letzler \& Tasoff 2013). If the goal is to help poor people to become self-sufficient, a focus on cognitive or bandwidth limits, and on the adverse effects of programs that strain those limits, might move policy in better directions (Mullainathan \& Shafir 2013). With respect to healthy diets, a disclosure requirement that informs consumers is far better than one that confuses them, and the fact that psychological research helps to explain and clarify consumer reactions is not a problem. (A qualification is that those nations that have some kind of "nudge unit," or behavioral insight team, do begin with people who have psychological or behavioral training, and who are able to bring that training to bear.)

It is also important, of course, for any uses of psychology - for example, to inform default rules or disclosure requirements - to be open and transparent rather than covert and hidden. In democratic societies, citizens are entitled to know what their government is doing and why. In the United States, uses of behavioral science have been open and subject to public scrutiny, usually through the official process for obtaining public comment (Sunstein 2013a).

\section{Paternalism and Psychology}

It is also true that in some nations, approaches might be highly controversial if and because they are paternalistic (Rebonato 2012). 
(Not incidentally, the diverse reactions to paternalistic approaches, across nations, might themselves be subject to empirical research, including psychological research; some nations, such as Denmark and Singapore, appear far more comfortable with paternalism than others, such as the United States and Germany.) But as we have seen, many psychologically informed policies are intended simply to help to make life more easily navigable, and there is nothing paternalistic about that. Indeed increased navigability is a large goal of many recent reforms. Consider, for example, the rejection of the confusing Food Pyramid, and efforts to make regulations simple to understand. It is important to emphasize that insofar as the goal is to increase navigability, paternalism need not be involved in any way (Norman 2013).

It is true that some people, including the present author, have defended forms of "libertarian paternalism" (Thaler \& Sunstein 2008), which preserve freedom of choice while also steering people in a certain direction. Examples include disclosure of information, warnings, and default rules, all of which allow people to go their own way (see also Appendix). A reasonable debate is certainly possible with respect to that form of paternalism (Rebonato 2012, Sunstein 2013a). If the goal is simply to protect human welfare, there may be a credible argument for coercive paternalism (Conly 2012), and libertarian paternalism, which can produce significant benefits at low cost, often has strong welfarist justifications.

Much could be said on this topic (see ibid. for detailed discussion). There are two central points in favor of libertarian paternalism as distinguished from libertarianism, full stop. The first is that decades of work of psychology and behavioral science have shown that human beings sometimes err, reducing their own well-being in the process (Thaler \& Sunstein 2008; Kahneman, 2011). If, for example, people suffer from "present bias," or display unrealistic optimism (Sharot 2011), or procrastinate, their lives might be improved or perhaps even saved by helpful information, warnings, reminders, or default rules. Impressed by the psychological findings, some people have argued for coercive paternalism on the ground that it can improve people's welfare and even their autonomy (Conly 2012, Bubb \& Pildes 2014). But it is not necessary to go so far to urge that freedom-preserving approaches can be helpful.

The second point is that some form of choice architecture is unavoidable (Thaler \& Sunstein 2008; cf. Norman 2013), and hence both private and public sectors are likely be nudging people even if they claim not to be doing so. Those in the private sector are frequently aware of that fact, and whether or not they consciously invoke 
psychological research, their choices about order, colors, sizes, noise, and placement will reflect at least implicit psychological judgments. Any cafeteria has to display items in a certain order, and that order will affect choices (Wansink 2014). If the government issues forms, discloses information, or maintains website, it will be creating choice architecture, and thus influencing what people will do. Those who reject libertarian paternalism must grapple with the extent to which social influences, and perhaps certain forms of paternalism, are inevitably in place (ibid.).

To be sure, it would be possible for government to attempt to minimize the number of nudges (Glaeser 2006, Rebonato 2012). Should it? The answer ought to depend on judgments about both welfare or autonomy. At the very least, there is a strong argument that welfare is often promoted by soft forms of paternalism, and that autonomy is not jeopardized (Sunstein 2013a). To be sure, manipulation should be avoided, and transparency is exceedingly important. People should not be deceived or fooled. To make sensible evaluations, it is best to investigate particular initiatives and details, rather than to proclaim in the abstract (Conly 2012). A testing question: Of the psychologically informed policies catalogued here, which, exactly, is objectionable as illegitimate paternalism? Another testing question: Who would prefer a policy that pays no attention to the psychology of the people it is supposed to benefit?

\section{Institutional Design}

There are also institutional questions. We could imagine a system in which an understanding of psychological findings is used by existing officials and institutions. For example, the relevant research could be enlisted by those involved in environmental protection, in health care, or in combatting infectious diseases and obesity. Officials with wellestablished positions - like my own as Administrator of the White House Office of Information and Regulatory Affairs, from 2009 to 2012 - might be expected to use that research, at least on occasion. If such officials have genuine authority, they might be able to produce significant reforms, simply because they are not akin to a mere research arm or a think-tank, but on the contrary have "line authority." This was the essential pattern during the first term of the Obama Administration.

A different approach would be to create a new institution - a behavioral insights team, a "nudge unit," or something akin to a Council of Psychological Advisers. The advantage of such an approach is that it 
would have a dedicated team, specifically devoted to the relevant work. If the team could conduct its own research, including randomized controlled trials, it might be able to produce important findings (as has in fact been done in the United Kingdom, and similar efforts are underway elsewhere). The risk of such a team is that it could be akin to an academic adjunct, without the ability to initiate real reform. Authority greatly matters. In this domain, one size does not fit all, and different nations can reasonably make different choices. But it is noteworthy that many nations (including the United States) have concluded that it is worthwhile to have a dedicated team. Of course the two approaches might be complementary.

\section{Well Beyond Incentives}

Many officials are aware that if the goal is to alter behavior, it is best to alter material incentives. When the price of certain activity increases, there will be less of it. But psychologists have shown that for material incentives to work, they have to attract people's attention, and also that to make policies sensibly, policymakers have to combine an understanding of incentives with an appreciation of human complexity and choice architecture. Sometimes people's responses are quite different from what was anticipated (Loewenstein et al. 2014b) - often in degree, and sometimes even in direction.

An understanding of human behavior helps to uncover a series of new tools. It also shows the great importance of increased simplification and (perhaps above all) navigability (cf. Norman 2013). There is no substitute for empirical testing, and we should expect a significant increase in randomized controlled trials in the coming decades. We may not see nations creating Councils of Psychological Advisers, but all over the world, governments will enlist psychological findings, and behavioral science more generally, in the interest of achieving policy goals. 


\section{Appendix: List of Freedom-Preserving Tools (or "Nudges")}

(1) default rules (eg, auto-enrollment in programs, including education, health, savings)

(2) simplification and easing of current requirements (in part to promote take-up)

(3) required active choosing (requiring people to make an explicit choice)

(4) prompted choice (people are asked a question without having to answer)

(5) simplified active choosing (where people are asked whether they want to choose or instead to rely on a default rule)

(6) enhanced or influenced active choosing (eg, asking people to choose but using order effects or loss aversion to influence choices; alternatively, enlisting authority to influence people)

(7) efforts to make contexts or policies easily navigable, with pointers and guides (cf. GPS)

(8) reminders or "accessible counts and accounts" (eg, by email or text message, as for overdue bills; could be personalized; reminder apps; health-related wristbands, watches, or apps)

(9) priming (perhaps by emphasizing an relevant feature of the situation, such as its effect on people's future selves, or an aspect of people's identity, such as their inclination to be honest)

(10) eliciting implementation intentions or commitments ("do you plan to vote?")

(11) anchoring (starting with certain figures, eg, "do you want to give $\$ 200$ to this charity"?)

(12) uses of social norms (emphasizing what most people do, eg, "most people plan to vote" or "most people pay their taxes on time" or "most people are eating healthy these days")

(13) order effects (what people see 1st on a website or in a room; asking people to sign forms on first page)

(14) enlisting loss aversion ("you will lose \$X if you do not use energy conservation techniques," or alternatively, and a bit beyond a nudge, a small tax, eg 5-cent tax for plastic bags)

(15) increases in ease/convenience (e.g., making low-cost options or healthy foods visible)

(16) framing ("90 percent fat-free" vs. "10 percent fat") (loss frame vs. gain frame)

(17) disclosure (as in calorie counts or traffic lights systems for food)

(18) warnings, graphic or otherwise (as for cigarettes; might counteract optimistic bias)

(19) literal or figurative "speed bumps" or cooling off periods (as for waiving rights)

(20) formal precommitment strategies (as in Save More Tomorrow)

(21) automatic enrollment with precommitment (auto-enrollment in Save More Tomorrow)

(22) visual effects, colors, picture, signs, noises, fonts (eg, to promote highway safety or attention to one's future self, as in "virtual aging" through online programs)

(23) plain language; decreasing vagueness and ambiguity ("Plate, not Pyramid")

(24) efforts to attract or reduce attention, including through drawing attention to certain product attributes or through product placement (for example, through cafeteria design)

(25) using moral suasion, increasing fun, or triggering a sense of responsibility

(26) checklists (as for doctors or administrators)

(27) paperwork reduction (including prepopulation or elimination of forms)

(28) giving comparative information (to overcome "comparison friction") 
(29) informing people of nature and consequences of their own past choices ("midata")

(30) joint rather than separate evaluation of goods/people (might reduce discrimination)

(31) structuring choices (as through pointers or eliminating rarely chosen options) 


\section{Bibliography}

Agarwal S, Chomsisengphet S, Mahoney N, Stroebel J. 2013. Regulating Consumer Financial Products: Evidence from Credit Card. Work. Pap., NBER

Allcott H. 2011. Consumers' perceptions and misperceptions of energy costs. Am. Econ. Rev. 101(3): 98-104

Banerjee, A, Duflo E. 2012. Poor Economics. New York: Public Affairs.

Bar-Gill 0. 2012. Seduction By Contract. New York: Oxford University Press

Benartzi S, Thaler R. 2013. Behavioral economics and the retirement savings crisis. Science 339:1152-1153

Benartzi, S. 2012. Save More Tomorrow: Practical Behavioral Finance Solutions to Improve 401(k) Plans. New York: Portfolio/Penguin

Beshears J, Choi J, Laibson D, Madrian B. 2010. The Limitations of Defaults. Work. Pap., NBER

Bettinger EP, Long BT, Oreopoulos P, Sanbonmatsu L. 2009. The Role of Simplification and Information in College Decisions: Results from the H\&R Block FAFSA Experiment. Work. Pap., NBER

Bohnet, I, Bazerman, M, Van Gean, A. 2012. When Performance Trumps Gender Bias: Joint Versus Separate Evaluation, available at http://papers.ssrn.com/sol3/papers.cfm?abstract_id=2087613

Brehm, JW, Brehm, R. 1981. Psychological Reactance: A Theory of Freedom and Control. Mahwah, New Jersey: Erlbaum

Bronchetti ET, Dee TS, Huffman DB, Magenheim E. 2013. When a nudge isn't enough: Defaults and saving among low-income tax filers. Natl. Tax J. 66(3):609-634

Brown JR, Kling JR, Mullainathan S, Wrobel MV. 2008. Why don't people insure late-life consumption? A framing explanation of the underannuitization puzzle. Am. Econ. Rev. 98(2):304-309 
Brown, Z., Johnstone, Nick \& Haščič, Ivan \& Vong, Laura \& Barascud, Francis2013. Testing the Effects of Defaults on the Thermostat Settings of OECD Employees, Energy Econ. 39: 128-134.

Brown JR. 2007. Rational and Behavioral Perspectives on the Role of Annuities in Retirement Planning. Work. Pap., NBER

Bubb, R. 2014. TMI? Why the Optimal Architecture of Disclosure Remains TBD. Michigan Law Review (forthcoming).

Bubb R, Pildes R. 2014. How behavioral economics trims its sails and why. Harv. Law Rev. 127:1593-1678

Cabinet Office. 2013. The Behavioural Insights Team. London, UK: Cabinet Office. http://www.cabinetoffice.gov.uk/behaviouralinsights-team

Carroll GD, Choi JJ, Laibson D, Madrian BC, Metrick A. 2009. Optimal defaults and active decisions. $Q$.J. Econ. 124(4):1639-1674

Cent. Medicare Medicaid Serv (CMS). 2010. Re: Express lane eligibility option. Washington, DC: CMS.

http://peerta.acf.hhs.gov/uploadedFiles/Express\%20Lane\%20Eli gibility\%20SHO\%20final\%202-4-10\%20508\%20ready.pdf

Cent. Medicare Medicaid Serv. 2011. Medicare Program; Changes to the Medicare Advantage and the Medicare Prescription Drug Benefit Programs for Contract Year 2012 and Other Changes. Fed. Regist. $76: 21432-577$

Chetty R, Friedman J, Leth-Petersen S, Nielsen T, Olsen T. 2012. Active vs. Passive Decisions and Crowdout in Retirement Savings Accounts: Evidence from Denmark. Work. Pap., NBER

Chetty R, Looney A, Kroft K. 2009. Salience and taxation: theory and evidence. Am. Econ. Rev. 99(4):1145-1177

Chiteji N, Walker L. 2009. Strategies to increase the retirement savings of African American households. In Automatic: Changing the Way America Saves, eds. G Gale, JM Iwry, DC John, L Walker, 10:231260. Washington, DC: Brookings Institution Press 
Cialdini RB, Demaine LJ, Sagarin BJ, Barrett DW, Rhoads K, Winter PL. 2006. Managing social norms for persuasive impact. Soc. Influence $1(1): 3-15$

Conly S. 2012. Against Autonomy. Cambridge, UK: Cambridge University Press

Dinner IM, Johnson EJ, Goldstein DG, Liu K. 2011. Partitioning default effects: why people choose not to choose. J. Experimental Psychol.: Applied 17(4):332-341

Directorate Gen. Health \& Consumers (DG SANCO). 2010. Consumer Behaviour: The Road to Effective Policy-Making. Brussels: DG SANCO. http://ec.europa.eu/consumers/docs/1dg-sancobrochure-consumer-behaviour-final.pdf

Dolan P. 2014. Happiness By Design. London: Hudson Street Press.

European Commission. 2012. Science for Environment Policy, Future Brief: Green Behavior. Brussels: European Commission. http://ec.europa.eu/environment/integration/research/newsaler t/pdf/FB4.pdf

European Parliament, Council of the European Union. 2011. Directive 2011/83/EU of the European Parliament and of the Council of 25 October 2011 on consumer rights. Off. J. Eur. Union 54(L 304):6488

Fed. Reserve System. 2009. Electronic Fund Transfers; Final Rule. Fed. Regist. 74:59033-54

Fed. Trade Commission (FTC). 2009. Negative Options: A Report by the Staff of the FTC's Division of Enforcement. Washington, DC: FTC. http://www.ftc.gov/os/2009/02/P064202negativeoptionreport.p df

Finkelstein A. 2009. E-ZTAX: Tax salience and tax rates. Q. J. Econ. 124(3):969-1010

Gale W, Iwry J, Walters S. 2009. Retirement savings for middle- and lower-income households: The Pension Protection Act of 2006 and the unfinished agenda. In Automatic: Changing the Way America 
Saves, eds. G Gale, JM Iwry, DC John, L Walker, 2:11-27.

Washington, DC: Brookings Institution Press

Glaeser E. 2006. Paternalism and Psychology. U. Chic. Law Rev. 73:133156

GreeNudge. 2014. GreeNudge. Oslo: GreeNudge.

http://www.greenudge.no/en/

Gruber J, Abaluck JT. 2011. Choice inconsistencies among the elderly: Evidence from plan choice in the Medicare Part D Program. Am. Econ. Rev. 101(4):1180-1210

Hallsworth M, List J, Metcalfe R, Vlaev I. 2014. The Behavioralist As Tax Collector: Using Natural Field Experiments to Enhance Tax Compliance. Work. Pap., NBER

Hardin R. The Crippled Epistemology of Extremism. 2002. In Political Extremism and Rationality. Cambridge: Cambridge University Press

Healthcare.gov. 2011. Providing Clear and Consistent Information to Consumers about Their Health Insurance Coverage. Retrieved from http://www.healthcare.gov/news/factsheets/labels08172011a.ht $\mathrm{ml}$ and

http://www.healthcare.gov/news/factsheets/labels08172011b.p df.

U.S. Dep. Health Human Serv. 2011. Rate Increase Disclosure and Review. Fed. Regist. 76: 29963-88

Heath C, Heath D. 2010. Switch: How to change things when change is hard. New York: Broadway

Hirshleifer D. 1995. The blind leading the blind: Social influence, fads, and informational cascades. In The New economics of human behavior, eds. M. Tommasi, K. Ierulli, 188-215. Cambridge, UK: Cambridge University Press

Howarth RB, Haddad BM, Paton B. 2000. The economics of energy efficiency: Insights from voluntary participation programs. Energy Policy 28(6-7):477-486 
Hu, YE, Vosgerau J, Morewedge C. 2014. Social Defaults: Observed Choices Become Choice Defaults. Journal of Consumer Research, 41: 741-757

Kahneman, D. 2011. Thinking, Fast and Slow. New York: Farrar, Straus and Giroux.

Kamenica, E., Mullainathan S, Thaler R. 2011. Helping Consumers Know Themselves. American Economic Review, 101(3): 417-22

Keys B., Pope D, Pope J. 2014. Failure to Refinance. NBER Working Paper No. 20401, available at http://www.nber.org/papers/w20401

Internal Revenue Service (IRS). 2009. Retirement \& Savings Initiatives: Helping Americans Save for the Future. Washington, DC: IRS. http://www.irs.gov/pub/irs-tege/rne_se0909.pdf

iNudgeYou.com. 2014. Resources. Odense, Denmark: iNudgeYou.com. http://www.inudgeyou.com/resources

Iyengar S, Kamenica E. 2010. Choice proliferation, simplicity seeking, and asset allocation. J. Public Econ. 94(7-8):530-539

Johnson E, Goldstein D. 2013. Decisions by default. In Behavioral Foundations of Policy, ed. E Shair. Princeton, NJ: Princeton University Press

Larrick R, Soll JB. 2008. The MPG illusion. Science, 320, 1593-1594.

Letzler R, Tasoff J. 2013. Everyone Believes in Redemption: Nudges and Overoptimism in Costly Task Completion. Available on ssrn.com

Loewenstein G, Bryce C, Hagmann D, Rajpal S. 2014a. Warning: You Are About to be Nudged. Work. Pap., SSRN

Loewenstein G, Sunstein CR, Golman R. 2014b. Disclosure: Psychology changes everything. Annu. Rev. Econ. 6:391-419

Low D. 2011. Behavioural Economics and Policy Design: Lessons from Singapore. Singapore: World Scientific Publishing Compan

Lunn, P. 2014. Regulatory Policy and Behavioural Economics. OECD. 
Madrian BC, Shea DF. 2001. The power of suggestion: Inertia in 401(k) participation and savings behavior. Q. J. Econ. 116(4):1149-1187

McKenzie, C. R. M., Liersch, M. J., \& Finkelstein, S. R. (2006).

Recommendations implicit in policy defaults. Psychological Science, 17, 414-420.

Mullainathan, S. 2007. Psychology and Development Economics. In Behavioral Economics and its Applications. (Diamond P. and Vartiainen H. eds). Princeton: Princeton University Press.

Mullainathan S, Shafir E. 2013. Scarcity: Why Having So Little Means So Much. New York: Times Books

Nickerson DW, Rogers T. 2010. Do you have a voting plan? Implementation intentions, voter turnout, and organic plan making. Psychol. Sci. 21(2):194-199

Norman D. 2013. The Design of Everyday Things. New York: Basic Books

Obama B. 2009a. Weekly Address: President Obama Announces New Initiatives for Retirement Savings. Washington, DC: White House Off. Press Secretary. http://www.whitehouse.gov/the_press_office/Weekly-AddressPresident-Obama-Announces-New-Initiatives-for-RetirementSavings

Obama B. 2009b. Federal Leadership On Reducing Text Messaging While Driving. Fed. Regist. 74:51225-27

Off. Management Budget (OMB). 2010. Information collection budget of the United States government. http://www.whitehouse.gov/sites/default/files/omb/inforeg/icb /icb_2010.pdf

Organisation for Economic Cooperation and Development (OECD). 2010. Consumer Policy Toolkit. Paris: OECD. http://www.oecd.org/sti/consumerpolicy/consumerpolicytoolkit. htm

Orszag P. 2010. OMB, Director, SAVEings. Washington, DC: OMB. http://www.whitehouse.gov/omb/blog/10/03/29/SAVEings/ 
Orszag PR, Rodriguez E. 2009. Retirement security for Latinos: bolstering coverage, savings, and adequacy. In Automatic: Changing the Way America Saves, eds. G Gale, JM Iwry, DC John, L Walker, 8:173-198. Washington, DC: Brookings Institution Press

Papke LE, Walker L, Dworsky M. 2009. Retirement savings for women: Progress to date and policies for tomorrow. In Automatic: Changing the Way America Saves, eds. G Gale, JM Iwry, DC John, L Walker, 9:199-230. Washington, DC: Brookings Institution Press

Pichert D, Katsikopoulos KV. 2008. Green defaults: Information presentation and pro-environmental behaviour. J. Environ. Psychol. 28:63-73

Rebonato R. 2012. Taking Liberties: A Critical Examination of Libertarian Paternalism. London: Palgrave Macmillan

Rozin P, Scott S, Dingley M, Urbanek JK, Jiang H, Kaltenbach M. 2011. Nudge to nobesity I: Minor changes in accessibility decrease food intake. Judgment \& Decision Making 6(4):323-332

Schwartz B. 2004. The Paradox of Choice. New York: HarperCollins

Schwartz B. 2012. Move over economists: We need a council of psychological advisers. The Atlantic, Nov. 12.

http://www.theatlantic.com/politics/archive/2012/11/moveover-economists-we-need-a-council-of-psychologicaladvisers/265085/

Sethi-Iyengar S, Huberman G, Jiang W. 2004. How much choice is too much? Contributions to 401(k) retirement plans. In Pension Design and Structure: New Lessons from Behavioral Finance, eds. OS Mitchell, SP Utkus. Oxford, UK: Oxford University Press

Sharot T. 2011. The Optimism Bias: A Tour of the Irrationally Positive brain. New York: Knopf Publishing

Shu L, Mazar N, Gino F, Ariely D, Bazerman M. 2012. Signing at the beginning makes ethics salient and decreases dishonest self-reports in comparison to signing at the end. Proc. Natl. Acad. Sci. USA 109(38): 15197-200 
Sunstein, CR and Hastie, R. 2015. Wiser: Getting Beyond Groupthink to Smarter Decisions. Cambridge: Harvard Business School Press.

Sunstein, CR. 2009. Going to Extremes. New York: Oxford University Press

Sunstein CR. 2010a. Administrator, OIRA, Memorandum for the Heads of Executive Departments and Agencies, Disclosure and Simplification as Regulatory Tools. Washington, DC: OMB. http://www.whitehouse.gov/sites/default/files/omb/assets/info reg/disclosure_principles.pdf

Sunstein CR. 2011a. Memorandum for chief information officers: Minimizing paperwork and reporting burdens. Washington, DC: OMB

Sunstein, CR. 2011b. Memorandum for the Heads of Executive Agencies and Departments: Informing Consumers through Smart Disclosure. Washington, DC: OMB.

Sunstein CR. 2013a. Simpler. New York: Simon \& Schuster

Sunstein CR. 2013b. Deciding by default. U. Pennsylvania Law Rev. 162(1):1-57

Sunstein, CR. 2014. Valuing Life: Humanizing the Regulatory State. Chicago: University of Chicago Press

Sunstein, CR. 2015a (forthcoming). Active Choosing or Default Rules? A Dilemma for Policymakers. Behavioral Science \& Policy

Sunstein, CR. 2015b (forthcoming). Choosing Not To Choose. London: Oxford Unievrsity Press

Sunstein CR, Reisch L. 2014. Automatically green: Behavioral economics and environmental protection. Harv. Environ. Law Rev. 38:127-58

Thaler RH, Sunstein CR. 2008. Nudge. New Haven: Yale University Press

Thaler RH. 2012. Watching behavior before writing the rules. New York Times, July 7. 
http://www.nytimes.com/2012/07/08/business/behavioralscience-can-help-guide-policy-economic-view.html

US Dep. Agric. (USDA). 2013. Direct Certification in the National School Lunch Program: State Implementation Progress, School Year 20122013: Report to Congress. Washington, DC: USDA. http://www.fns.usda.gov/direct-certification-national-schoollunch-program-state-implementation-progress-school-year-2012

US Dep. Agric. 2011a. Direct certification and certification of homeless, migrant and runaway children for free school meals. Fed. Regist. 76: $22785-802$

US Dep. Agric. 2011b. Dietary Guidelines 2010: Selected Messages for Consumers. Washington, DC: USDA. http://choosemyplate.gov/foodgroups/downloads/MyPlate/SelectedMessages.pdf

US Dep. Educ. 2010a. Program Integrity Issues. Fed. Regist. 75:66832975

US Dep. Educ. 2010b. Department of education establishes new student aid rules to protect borrowers and taxpayers. Washington, DC: US Dep. Educ. http://www.ed.gov/news/press-releases/departmenteducation-establishes-new-student-aid-rules-protect-borrowersand-tax

US Dep. Health and Human Serv. (HHS). 2010. Health care reform insurance web portal requirements. Fed. Regist.75:24470-82

US Dep. Treasury (Treasury). 2009. Financial Regulatory Reform: A New Foundation. Washington, DC: Treasury. http://www.treasury.gov/initiatives/wsr/Documents/FinalRepor t_web.pdf

US Dep. Treasury. 2008. U.S. Treasury Introduces Direct Express® Debit Card for Social Security Payments. Washington, DC: Treasury. http://www.fms.treas.gov/godirect/media/release/us-treasuryintroduces-direct-express-debit-card/index.html

US Environ. Protection Agency (EPA). 2009. Fuel economy labeling of motor vehicles: revisions to improve calculation of fuel economy estimates. Fed. Regist. 74:61537-55 
US Environ. Protection Agency, US Dep. Transport. 2010. Light-duty vehicle greenhouse gas emission standards and corporate average fuel economy standards. Fed. Regist. 75:25323-728

US Food Drug Admin (FDA). 2014a. Preliminary Regulatory Impact Analysis: Nutrition Facts/Serving Sizes. Washington, DC: FDA. http://www.fda.gov/downloads/Food/GuidanceRegulation/Guid anceDocumentsRegulatoryInformation/LabelingNutrition/UCM38 5669.pdf

US Food Drug Admin. 2014b. Deeming Tobacco Products to be Subject to the Food, Drug, and Cosmetic Act, as Amended by the Family Smoking Prevention and Tobacco Control Act; Regulations Restricting the Sale and Distribution of Tobacco Products and Required Warning Statements for Tobacco Product Packages and Advertisements. Washington, DC: US Food Drug Admin. http://www.fda.gov/downloads/AboutFDA/ReportsManualsFor ms/Reports/EconomicAnalyses/UCM394933.pdf

Wansink B. 2014. Slim By Design. New York: William Morrow.

Willis LE. 2013. When nudges fail: Slippery defaults. U. Chic. Law Rev. 80:1155-229

\section{Legal Citations to Statutes and CFR}

CLASS Act, Pub. L. No. 111-148, tit. VIII-IX, 124 Stat. 119 (2010) (codified at 42 U.S.C. $§ 300 l l(2012)$ )

Credit CARD Act, Pub. L. No. 111-24, 123 Stat. 1734 (2009) (codified in scattered sections of 15 and 16 U.S.C. (2012))

Dodd-Frank Wall Street Reform and Consumer Protection Act, Pub. L. No. 111-203, 124 Stat. 1376 (2010) (codified in scattered sections of the U.S.C. (2012))

Family Smoking Prevention and Tobacco Control Act of 2009, Pub. L. No. 111-31, 123 Stat. 1776 (codified at 21 U.S.C. 301 et seq. (2012))

Fed. Reserve Board Requirements for Overdraft Services, 12 C.F.R. $\S$ 205.17 
Fed. Trade Commission Use of Prenotification Negative Option Plans, 16 C.F.R. $§ 425$ (2013)

Healthy, Hunger-Free Kids Act of 2010, Pub. L. No. 111-296, 124 Stat. 3183 (codified in scattered sections of 42 U.S.C. (2012))

Occupational Safety \& Health Admin. Occupational Safety and Health Standards, 29 C.F.R. $§ 1910$ (2013)

Occupational Safety \& Health Admin. Occupational Safety and Health Standards for Shipyard Employment, 29 C.F.R. § 1915 (2013)

Occupational Safety \& Health Admin. Safety and Health Regulations for Construction, 29 C.F.R. $§ 1926$ (2013)

Patient Protection and Affordable Care Act, Pub. L. No. 111-148, 124 Stat. 119 (2010) (codified in scattered sections of 26 and 42 U.S.C. (2012))

Pension Protection Act of 2006, Pub. L. No. 109-280, 120 Stat. 780 (codified in scattered sections of 26 and 29 U.S.C. (2012))

US Dep. Agric. Nutrition Label Content, 9 C.F.R. § 317.309 (2013)

US Dep. Educ. Reporting and Disclosure Requirements for Programs That Prepare Students For Gainful Employment in a Recognized Occupation, 34 C.F.R. $§ 668.6$ (2013)

US Dep. Labor Fiduciary Requirements for Disclosure in ParticipantDirected Individual Account Plans, 29 C.F.R. § $2550.404 a-5$ (2013) 